Vergara, P. M., L. O. Meneses, M. Saavedra, F. E. Diaz, K. Norambuena, A. Fierro, A. D. Rodewald, and G. E. Soto. 2017. Magellanic Woodpeckers in three national parks of central-southern Chile: habitat effects and population variation over the last two decades. Avian Conservation and Ecology 12(2):15. https://doi.org/10.5751/ACE-01106-120215

Copyright (C) 2017 by the author(s). Published here under license by the Resilience Alliance.

Research Paper

\title{
Magellanic Woodpeckers in three national parks of central-southern Chile: habitat effects and population variation over the last two decades
}

\author{
Pablo M. Vergara ${ }^{1}$, Luis O. Meneses ${ }^{1}$, Marcelo Saavedra ${ }^{2}$, Felipe E. Diaz ${ }^{1}$, Katherine Norambuena ${ }^{1}$, Andrés Fierro ${ }^{1}$, Amanda D. \\ Rodewald ${ }^{3}$ and Gerardo E. Soto ${ }^{3}$ \\ ${ }^{1}$ Universidad de Santiago de Chile, ${ }^{2}$ Corporación Nacional Forestal, ${ }^{3}$ Cornell Lab of Ornithology and Department of Natural \\ Resources, Cornell University, Ithaca, NY, USA
}

\begin{abstract}
A major challenge for protected areas is providing wildlife with enough suitable habitat to cope with stochastic environment and increased pressure from the surrounding landscapes. In this study, we addressed changes in local populations of Magellanic Woodpeckers (Campephilus magellanicus) occupying three national parks of central-southern Chile. We compared the breeding and postbreeding abundance of woodpeckers during the 1990s with the present (2016) abundance ( $n=4$ years), and assessed the extent to which abundance was explained by forest type and quality of foraging habitat (as quantified through the plant senescence reflectance index; PSRI). Results show a distinctive temporal variation in woodpecker abundance at each park, with local populations of Magellanic Woodpeckers declining by $42.2 \%$ in Conguillío National Park, but increasing by $34.3 \%$ in Nahuelbuta National Park. Woodpeckers responded to forest conditions within each park such that their abundance increased with high quality of foraging habitat, i.e., large PSRI values, and the presence of old-growth Monkey puzzle (Araucaria araucana) - Nothofagus pumilio mixed forest. Anecdotal evidence suggests that populations of woodpeckers in Conguillío National Park might have responded negatively to large-scale disturbances from recent forest fires affecting part of the forest area within park. Because stochastic events seemed to strongly mediate population changes, our findings suggest that regional conservation of Magellanic Woodpeckers requires expanding the current conservation area network in central-southern Chile.
\end{abstract}

\section{Le Pic de Magellan dans trois parcs nationaux du centre-sud du Chili : effets de l'habitat et variation des populations durant les deux dernières décennies}

RÉSUMÉ. Les aires protégées font face au défi important de fournir suffisamment d'habitat propice à la faune pour compenser le côté imprévisible de l'environnement et les pressions grandissantes provenant des paysages voisins. Dans le cadre de la présente étude, nous avons évalué les changements advenus dans les populations locales du Pic de Magellan (Campephilus magellanicus) qui fréquentent trois parcs nationaux du centre-sud du Chili. Nous avons comparé les effectifs de ce pic en nidification et en post-nidification dans les années 1990 avec ceux de 2016 ( $n=4$ années), et évalué dans quelle mesure les effectifs étaient reliés au type forestier et à la qualité des aires d'alimentation (quantifiée par l'indice de réflectance de la sénescence végétale; en anglais PSRI). Nos résultats montrent une variation temporelle des effectifs de pics distincte dans chaque parc : la population locale de Pics de Magellan a diminué de $42,2 \%$ dans le parc national Conguillío, mais a augmenté de 34,3\% dans le parc national Nahuelbuta. Les pics se sont adaptés aux conditions forestières dans chaque parc, de sorte que leur abondance a augmenté là où les aires d'alimentation étaient de grande qualité, c.-à-d. avec des valeurs de PSRI élevées, et en fonction de la présence de forêt mélangée âgée de Désespoir du singe (Araucaria araucana) Nothofagus pumilio. Des observations anecdotiques laissent croire que la population de pics du parc national Conguillío pourrait avoir réagi négativement aux perturbations à grande échelle causées par les récents feux de forêt qui ont touché une partie de la superficie forestière du parc. Puisque les événements imprévisibles semblent avoir un effet important dans les changements de population, nos résultats indiquent que la conservation régionale du Pic de Magellan profiterait d'une expansion du réseau actuel d'aires de conservation dans le centre-sud du Chili.

Key Words: Campephilus magellanicus; national parks; population changes

\section{INTRODUCTION}

Conserving biodiversity in an increasingly human-dominated world requires, in part, the establishment of protected areas that can support viable populations of species of conservation concern (Wilson 1989, Pauchard and Villaroel 2002, IUCN 2017).
Fortunately, there are many success stories around the world where national legislation and international agreements have facilitated the design and implementation of networks of protected areas, including national parks or reserves. However, the effectiveness of these protected areas in maintaining viable populations of plants and animals is usually difficult to

Address of Correspondent: Pablo M. Vergara, Avenida Libertador Bernardo O'Higgins nº 3363, Estación Central, Santiago, pablo.vergara@usach.cl Erratum: Figures 2 and 3 have been changed since the original publication of this paper. The correction was made on 5 Dec. 2015. 
demonstrate (Bücking 2003, Rodrigues et al. 2004). A major challenge for protected areas is providing wildlife with sufficient habitat of high quality, especially when faced with stochastic environments and increased pressure from the surrounding landscapes (Roux et al. 2008, Paudel and Heinen 2015).

The role of protected areas in biodiversity conservation is particularly critical for rare, endangered, or unique ecosystems (Noss 2000, Noss et al. 2015), yet seldom explicitly examined. The temperate rainforests of central-southern Chile are one exception because the current network of national protected areas (known as SNASPE; see Squeo et al. 2012) has been scientifically challenged regarding its capacity to support viable populations of forest-dependent wildlife (Tognelli et al. 2008, Squeo et al. 2012). Since the 1940s Chilean conservation areas, including national parks and forest reserves, have been designated to protect natural scenic landscapes containing temperate rainforest and montane areas that receive relatively little pressure from humans (Otero 2001). Nevertheless, the amount of undisturbed temperate forest protected under Chilean law may be insufficient for meeting conservation goals (Tognelli et al. 2008). The potential insufficiency of forest habitat derives, in part, from high vulnerability to natural disasters, e.g., landslides or volcanic eruptions, that regularly occur within the Andes Mountains, as well as human-induced disturbances, such as large fires intensified by regional summer drought (González et al. 2005). The relatively modest area of forest currently being protected by the southern Chile national parks, in combination with the increased risk of large-scale disturbances, raises important questions about the ability of parks to conserve forest species (e.g., Araújo et al. 2002). One approach to evaluating the effectiveness of central-southern Chilean national parks for conserving wildlife populations is to quantitatively assess population status of species of conservation concern (Parks et al. 2013, Burns et al. 2016).

In this study, we address midterm changes (20 years) of local populations of Magellanic Woodpeckers (Campephilus magellanicus) occupying central-southern Chilean national parks. The Magellanic Woodpecker is the largest woodpecker species in South America and the main primary cavity excavator of the southern temperate rainforests (Short 1970, Vergara and Schlatter 2004, Ojeda and Chazarreta 2006). Like other large woodpecker species, Magellanic Woodpeckers have relatively long parental care duration (two to three years), large territories $\left(0.2\right.$ to $\left.1.3 \mathrm{~km}^{2}\right)$ and low densities ( 0.1 to 1.8 individuals $\left./ \mathrm{km}^{2}\right)$, which make them highly sensitive to forest loss and degradation caused by logging, wildfires, and natural disasters (Vergara and Schlatter 2004, Chazarreta et al. 2011, Soto et al. 2012, Ojeda and Chazarreta 2014, Vergara et al. 2014; see also Lammertink et al. 2009). Specifically, the loss of large, dying, or dead trees reduces availability of foraging, roosting, and nesting sites and, thus, induces population declines across multiple species of woodpeckers (Lammertink 2004, 2014, Mikusinski 2006, Bull et al. 2007, Pasinelli 2007, Lammertink et al. 2009, Kumar et al. 2014, Nappi et al. 2015). Remote sensing-based methods have proven to be effective in identifying trees with advanced decay stages, thus providing information on the quality of foraging habitat of Magellanic woodpeckers (Vergara et al. 2016, Vergara et al. 2017, Soto et al. 2017). Accelerating loss and degradation of forests have constricted the distribution of several woodpecker species, and some viable populations of the woodpecker are now confined to protected areas surrounded by productive lands (Setterington et al. 2000, Melletti and Peteriani 2003, Roberge et al. 2008a).

The Magellanic Woodpecker lives in family groups (between two to five individuals), establishing territories that are relatively stable between seasons and consecutive years (Ojeda and Chazarreta 2014), thus making them an appropriate species to assess temporal changes in abundance (e.g., see Pasinelli 2006, Drever et al. 2008, Drever and Martin 2010, Vergara et al. 2016). Although the breeding biology and foraging behavior of Magellanic Woodpeckers have been described previously (Short 1970, Vergara and Schlatter 2004, Schlatter and Vergara 2005, Chazarreta et al. 2012, Espinosa et al. 2016, Soto et al. 2016, Vergara et al. 2016), to date, no study has evaluated their population dynamics. Temporal fluctuations in the population size of large-bodied woodpecker species remain poorly understood because of rarity and low demographic rates (but see Mattsson et al. 2008). Adding complexity, the level of threats facing Magellanic woodpeckers varies geographically (Ojeda et al. 2011). The most significant contributions to the conservation of global population of Magellanic Woodpeckers likely are the native forests currently protected under the SNASPE, which are concentrated in the Patagonian and Sub-Antarctic Ecoregions $\left(40^{\circ} 00^{\prime} \mathrm{S}\right.$ to $\left.55^{\circ} 30^{\prime} \mathrm{S}\right)$ and comprise 40 conservation areas $\left(\sim 115,000 \mathrm{~km}^{2}\right)$ facing relatively low human pressure. Conversely, woodpeckers living in the relatively small national parks located in central-southern Chile (north of $40 \mathrm{~S}$ ) may be highly vulnerable to native forest replacement by exotic plantations and agricultural lands. In this study, we compared the abundance of Magellanic woodpeckers during the 1990s with that of the present (2016) in central-southern Chile's national parks surrounded by different matrix types and identified the habitat features that best explain variation in local abundance.

\section{METHODS}

\section{Study area}

We focused our study on three national parks in the Araucanía region of central-southern Chile (between 900 and $1450 \mathrm{~m}$ altitude), including Nahuelbuta National Park $\left(63 \mathrm{~km}^{2} ; 37.81 \mathrm{~S}\right.$, $72.99 \mathrm{~W})$, Tolhuaca National Park (64 km²; $38.22 \mathrm{~S}, 71.83 \mathrm{~W})$, and Conguillío National Park $\left(545 \mathrm{~km}^{2} ; 38.69 \mathrm{~S}, 71.68 \mathrm{~W}\right)$. These national parks differ in their amount of native forest, with Nahuelbuta, Tolhuaca, and Conguillío comprising, respectively, $61.91 \mathrm{~km}^{2}(98.2 \%), 30.36 \mathrm{~km}^{2}(47.4 .2 \%)$, and $230.72 \mathrm{~km}^{2}(42.3 \%)$. Nahuelbuta national park is the only protected area within the Coastal mountain range, while the other two parks are located along the Andes mountain range (Fig. 1). Soils in Congullio and Tolhuaca parks are derived from recently deposited volcanic ashes and scoria, while Nahuelbuta park has clayey soils developed on metamorphic rocks. Nonforest vegetation in Congullio and Tolhuaca parks includes perennial grasses, scrub, cushion plants, mosses, and lichens growing on volcanic rocks, while in Nahuelbuta park it includes shrub vegetation in degraded forest. All national parks were located adjacent $(<10 \mathrm{~km})$ to highly fragmented landscapes dominated by exotic plantations and agricultural areas (Fig. 1). Because these parks have been protected for over 80 years, their forests have remained mostly intact and free from logging activities since then. Forests are 
Fig. 1. Map showing the study national parks, including the remaining native forest (dark gray) and open lands used for forestry or farming (gray). Boundaries represent the limits of the administrative region where the national parks in the study area are located.

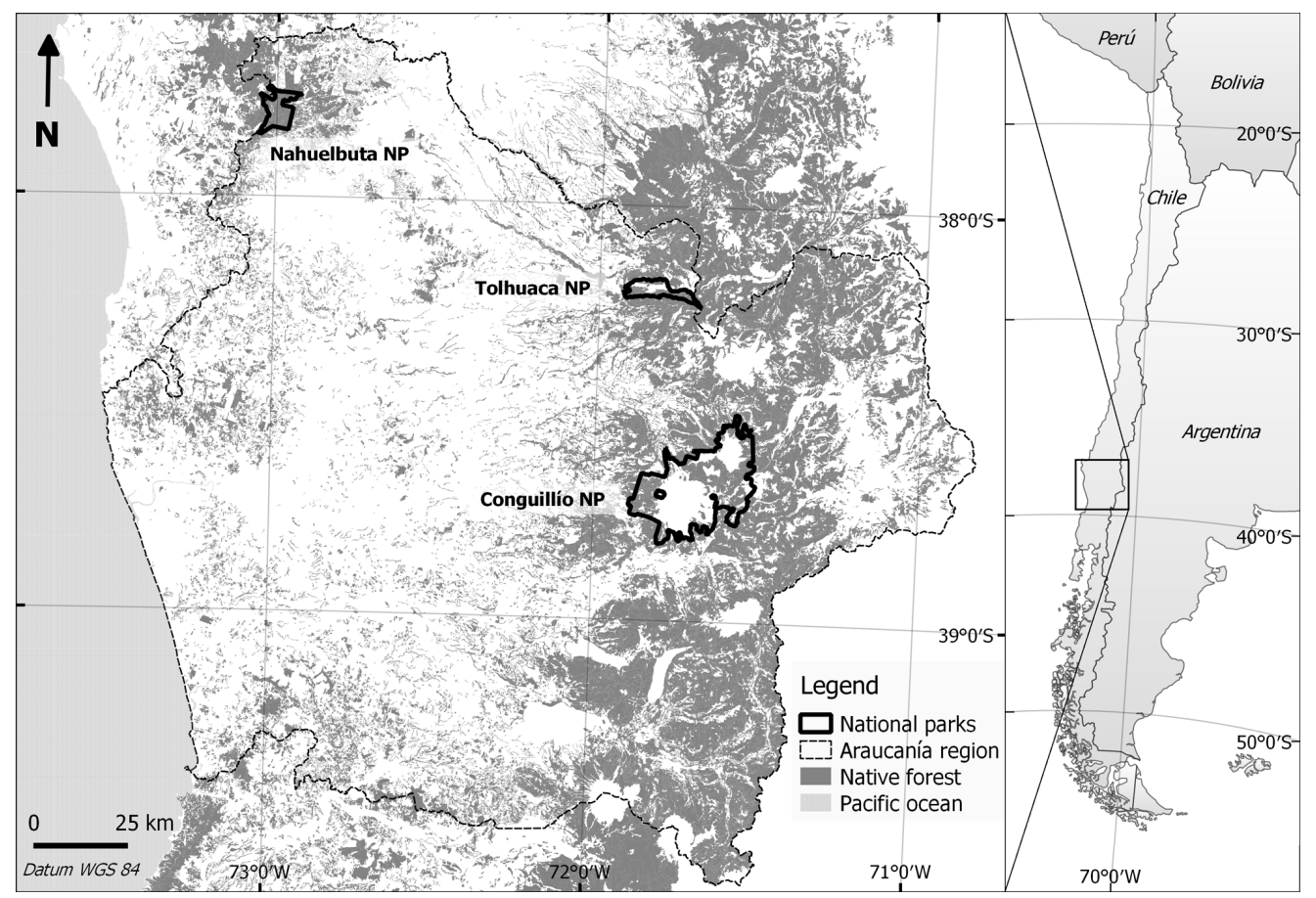

mainly made up of different species of southern beech trees (genus Nothofagus) mixed with the Monkey puzzle tree (Araucaria araucana), including the following forest types: (1) old-growth $N$. pumilio and Monkey puzzle forest; (2) old-growth $N$. antarctica and Monkey puzzle forest; (3) old-growth N. dombeyi, N. pumilio, and Monkey puzzle forest; and (4) second-growth N. antarctica forest (Espinosa et al. 2016). Conguillío National Park, mostly made up of pristine forests, experienced the eruption of Llaima Volcano in 2008, where lahar flows affected part of the protected forest and volcanic ash was deposited on the forest canopy. In addition, anthropogenic large-scale (> 1000 ha) fire events occurred recently in Conguillío National Park (summer 2015) and Tolhuaca National Park (summer 2002).

\section{Abundance surveys}

Abundance of woodpeckers was monitored during the breeding season (austral spring) and postbreeding season (austral summer) in the late 1990s (i.e., 1995-1998) and during 2016. In each national park, we conducted 8 min (Vergara et al. 2010) point count surveys in 34 sites: 18 points in Conguillío National Park, 13 points in Nahuelbuta National Park, and 3 points in Tolhuaca National Park. Sampling points were randomly established in stands of different forest types (Table 1), at least $100 \mathrm{~m}$ from the stand edge. Because adult Magellanic Woodpeckers are conspicuous, noisy (e.g., Vergara et al. 2016), and thus easily detected, we recorded all woodpeckers seen and heard within 100m-radius (e.g., Ralph et al. 1993). A single trained observer annually visited each point up to eight times between 1995 and 1998, and three to five times between November and March 2016.
Table 1. Variables characterizing the habitat of Magellanic Woodpeckers (Campephilus magellanicus) in the study area national parks, including forest type and the plant senescence reflectance index (PSRI) positively associated with tree decay stage. Forest type variables represent the percentage of plots being categorized as belonging to a particular forest type. All habitat variables were measured within $100 \mathrm{~m}$ around point counts used to monitor abundance of woodpeckers. The percentage of points surveyed in each forest type, as well as the mean (SD) of PSRI is shown for each national park.

\begin{tabular}{lccc}
\hline \hline Variable & \multicolumn{3}{c}{ National park } \\
\cline { 2 - 4 } & Tolhuaca & Conguillio & Nahuelbuta \\
\hline $\begin{array}{l}\text { Monkey puzzle tree }-N . \\
\text { dombeyi forest }\end{array}$ & $0.0 \%$ & $38.9 \%$ & $46.2 \%$ \\
$\begin{array}{l}\text { Monkey puzzle tree }-N . \\
\text { pumilio forest }\end{array}$ & $66.7 \%$ & $33.3 \%$ & $0.0 \%$ \\
$\begin{array}{l}\text { Monkey puzzle tree - } N . \\
\begin{array}{l}\text { Antarctica forest } \\
N \text {. antarctica forest }\end{array}\end{array}$ & $0.0 \%$ & $11.1 \%$ & $15.4 \%$ \\
$\begin{array}{l}\text { Plant Senescence } \\
\text { Reflectance Index (PSRI) }\end{array}$ & $-0.63(0.032)$ & $-0.65(0.057)$ & $-0.61(0.074)$ \\
\hline
\end{tabular}

Monkey puzzle tree, Araucaria araucana.

Points were spaced at least $500 \mathrm{~m}$ apart to reduce spatial autocorrelation arising from neighborhood effects. In order to increase detection probability, during 2016 the observer carried out an additional 8 min-long "active" survey by using a 
"drumming device" (DD) once every minute. The DD is a wooden box used with drum sticks to imitate the double-tap territorial drum that Magellanic Woodpeckers and other campephiline species make while patrolling their territories (Soto et al. 2016, Vergara et al. 2016). It produces a sound that is comparable to that broadcasted during playback surveys, but that is louder and more resonant than sound played from an electronic device (Saracco et al. 2011, Fogg et al. 2014). Abundance estimates derived from active surveys should be greater than those from passive surveys (without using the DD), being reflected by differences in detection probability between census techniques (see the Data analysis section).

\section{Habitat variables}

Forest habitat was characterized within $100 \mathrm{~m}$ around each point count using remote sensing (WorldView-2 and -3, and Landsat-8) and a GIS database of forest types (CONAF 2011). We estimated the plant senescence reflectance index (PSRI; Merzlyak et al. 1999), a measure of tree senescence, i.e., wood decay (Soto et al. 2017; Table 1). PSRI uses red and green bands to measure chlorophyll degradation and carotenoid content of the tree canopy, with higher values indicating more advanced decay stage of trees (e.g., see Soto et al. 2017). Previous studies have demonstrated that Magellanic Woodpeckers select individual trees based on their PRSI values (see details in Vergara et al. 2016). These tree preferences are consistent with the occurrence pattern of the long-horned beetle Microplophorus magellanicus, one of the main prey of woodpeckers, which respond positively to tree senescence (Vergara et al. 2017). In addition, tree senescence is a reliable indicator of the occurrence of nest-sites of woodpeckers because these cavities are easier to excavate in decayed trees (e.g., Blanc and Martin 2012, Zahner et al. 2012). We used WorldView-2 and -3 satellite imagery, which provide high spatial and spectral resolutions ( $0.5 \mathrm{~m}$ pixel size and 8 spectral bands), allowing a precise estimation of tree attributes. First, the satellite imagery was geometrically and atmospherically corrected. Next, a digital supervised classification was carried out to discriminate between forest and nonforest land cover classes using ENVI v. 5.0, then we determined the percentage of forest cover within the detection distance of point count surveys (see above). Finally, PSRI was averaged on each of the 100-m-radius circular plots centered on each point. Forest type was quantified as a factor describing the dominant forest type around each point (Table 1).

\section{Data analysis}

We used a N-mixture Bayesian model (Royle 2004) to estimate the abundance of woodpeckers at the $i=1,2, \ldots R$ sites (pointcount locations), at the year $\mathrm{t}$, on each sampling replicate $(t=1$, $2, \ldots T)$. We considered a multiyear dynamic model that assumes the population is demographically closed within each year (e.g., see dynamics models for woodpeckers in Fogg et al. 2014). The number of distinct woodpeckers counted at point $i$ in year $j$ and occasion $t\left(n_{i j t}\right)$ was modeled as an independent realization of a Binomial random variable dependent on the actual number of woodpeckers at point $i$ in year $j\left(N_{i j}\right)$ and the detection probability at $t\left(p_{i j t}\right)$, such that $n_{i j} \sim \operatorname{Binomial}\left(N_{i j}, p_{i j t}\right)$ with mean $p N$.

The actual number of woodpeckers at a point is a latent, unobserved Poisson distributed variable, $N_{i j} \sim \operatorname{Poisson}\left(\lambda_{i j}\right)$, where $\lambda_{i j}$ represents the average abundance at site $i$ in year $j$ and is modeled as a function of independent covariates:

$$
\begin{aligned}
\log \left(\lambda_{i, j}\right)=\beta_{0} & +\beta_{1} H_{i}+\beta_{2} Y+\beta_{3} P S R I_{i} \\
& +\beta_{4} H_{i} \times Y+\beta_{5} P S R I_{i} \times Y
\end{aligned}
$$

where $\beta_{k=0,1, . .5}$ is the $k^{\text {th }}$ fixed-effect coefficient (of $k$ total coefficients, including an intercept). Covariates in Equation 1 were specified as follows: (1) Survey year (Y) is a factor with four levels, one for each survey year, i.e., 1996, 1997, 1998, and 2016; (2) Forest type $(\mathrm{F})$ is a factor with four levels, one for each forest type, i.e., N. dombeyi - Monkey puzzle, Monkey puzzle - N. pumilio, Monkey puzzle - N. Antarctica and N. antarctica; (3) PSRI is a continuous variable ranging between -0.8 and -0.5 ; (4) Interactions between the above explained covariates, $\mathrm{Y} \times \mathrm{F}$ and $\mathrm{Y} \times$ PSRI.

The probability of detection $p_{i j t}$, at site $i$ during the year $j$ and sampling occasion $t$ was estimated with the following logit function:

$$
\begin{array}{r}
\operatorname{logit}\left(p_{i, j, t}\right)=\alpha_{0}+\alpha_{1} F_{i}+\alpha_{2} Y+\alpha_{3} F_{i} \times Y \\
+\alpha_{4} P S R I_{i} \times Y+\alpha_{5} S_{i}+\delta_{i}
\end{array}
$$

where is the $\mathrm{k}^{\text {th }}$ fixed-effect coefficient associated with the ability of observers to detect woodpeckers among different years (Y), seasons (S), and forest types (F). Annual turnover of individuals occupying territories, reproductive status and differences in conspicuousness between habitats may cause variation in the detection probability across years, seasons, and forest types, respectively. We controlled for spatial autocorrelation arising from counting the same woodpecker families at neighboring points by including a spatially structured term $(\delta)$ from a conditional autoregressive model (e.g., Chandler and Royle 2013). In a posterior analysis, we compared detection probabilities derived from passive and active surveys, both carried out during 2016 through a simplified function for the survey method $m$, at the site $i$, and during the time period $j$ ( $\mathrm{m}=1$ for passive and $\mathrm{m}$ $=2$ for active):

$$
\operatorname{logit}\left(p_{i, j, m, t}\right)=\gamma_{i, j, m, t}
$$

Parameter distributions and abundance estimates were based on three Markov Chain Monte Carlo (MCMC) samples, each with 20,000 iterations, discarding the first 10,000 iterations and thinning by 5. MCMC Convergence was visually examined and by using the potential scale reduction factor (Gelman et al. 2014). We evaluated 40 candidate models with different covariate combinations and ranked them by their deviance information criteria (DIC; Spiegelhalter et al. 2003). Models were run using OpenBUGS v. 3.2.3 (Lunn et al. 2009) via the R2OpenBUGS package of R v. 3.2.0 (Sturtz et al. 2005, R Development Core Team 2008). The regular and intensive sampling frequency in each survey point ( 20 surveys per point), the seasonal stability in site occupancy, and the reduced number of model covariates contributed to improve model fitting. Indeed, model estimation did not exhibit convergence problems despite the number of sampling points $(n=34$ points). The Bayesian credible intervals (BCI) estimated from posterior distribution of parameters was used to evaluate the importance of each. In addition, we estimated 
Table 2. The five best-ranked Bayesian N-mixture CAR candidate models used to predict the abundance of Magellanic Woodpecker (Campephilus magellanicus). Covariates included in abundance model and probability functions are shown separately. Deviance's information criterion (DIC), DIC difference with the lowest DIC model ( $\triangle \mathrm{DIC})$ and model weights $(\omega)$ are shown.

\begin{tabular}{|c|c|c|c|c|}
\hline Abundance function & Probability function & $\mathrm{DIC}$ & $\triangle \mathrm{DIC}$ & $\omega$ \\
\hline Forest & Year + Season & 5142.22 & 0.00 & 0.37 \\
\hline Forest + Year + PSRI & Forest + Year + Season & 5143.79 & 1.58 & 0.17 \\
\hline Forest $\times$ Year + Forest + Year + PSRI & Forest $\times$ Year + Forest + Year + Season & 5144.86 & 2.65 & 0.10 \\
\hline Forest + PSRI & Forest + Season & 5145.69 & 3.48 & 0.07 \\
\hline Forest & Season & 5146.20 & 3.99 & 0.05 \\
\hline
\end{tabular}

the p-values as the proportion of the sampled coefficients that were $>0$ (if the mean coefficient was positive) or $<0$ (otherwise).

In order to evaluate population trends, we estimated the yearly mean density (individuals $/ \mathrm{km}^{2}$ ) of woodpeckers from the bestsupported model (see model selection above). For each national park, the mean density of woodpeckers in year $j$ was estimated as: $D_{j}=\sum^{\mathrm{n}}$ mean $\left(N_{i j}\right) /(\mathrm{A} \times \mathrm{n})$, where mean $\left(N_{i j}\right)$ is the mean Bayesian estimate of the actual number of woodpeckers at a point $i$ (see above) drawn from the MCMC posterior distribution. $A$ and $n$ correspond, respectively, to the area of fixed-radius counts and the number of sampling points in each park. We determined if density values were statistically different between survey years by using their 95\% BCIs. Specifically, we determined if the BCI of each survey year overlaps with the mean density estimated for the other years. Despite the fact that the field data derived from this study provided only partial information for describing temporal trends in population size of woodpeckers, we aim to compare the population size over the last two decades (1990s vs. 2016). Thus, we reported for each park the percent of change or bidecadal change in density as: $100 \times\left(D_{2016}-D_{1990 \mathrm{~s}}\right) / D_{1990 \mathrm{~s}}$, where $D_{1990 \mathrm{~s}}$ and $D_{2016}$ are, respectively, the mean density for the 1990 decade and 2016. The significance of the bidecadal variation in density was assessed by examining its 95\% BCIs and calculating p-values, as explained above. The reduced number of sampling points in Tolhuaca National Park prevented the assessment of population trends in this national park. Therefore, population trends were assessed for Conguillío National Park and Nahuelbuta National Park only.

\section{RESULTS}

A total of 218 individuals were detected during 649 different field surveys at the 34 sampling points, averaging $4.9(\mathrm{SD}=2.1)$ visits per year and point (range: 4 to 7 visits). Detection probability $($ Mean \pm SD) did not differ between passive $(p=0.43 \pm 0.14)$ and active surveys $(p=0.45 \pm 0.15)$.

We found support $(\triangle D I C \leq 2)$ for two models explaining the abundance and detection probability of Magellanic Woodpeckers, with both models being better supported than the null model $(\triangle D I C=15.46)$. The most parsimonious candidate model included only the effect of forest type on the abundance, and the effect of year and season on the detection probability (Table 2). The second best supported candidate model $(\triangle D I C=1.58)$ retained the effect of forest type on the abundance, but also included the additive effect of year and PSRI (Table 2). The latter candidate model included the effect of year, season, and forest type on the detection probability (Table 2).
The coefficients of the best supported models (Table 3 ) showed a significant positive effect of the Monkey puzzle - $N$. pumilio forest on the woodpecker abundance, when compared to the other forest types (Table 3 ). The abundance of woodpeckers was also positively affected by the PSRI, as supported by the second-best model (Table 3; Fig. 2). Despite being included in the best supported models, neither year nor season had significant effect over the abundance or detection probability (Table 3). Bidecadal variation (1990s vs. 2016) in density of Magellanic Woodpeckers was significant ( $p<$ 0.05) in both Conguillío and Nahuelbuta National Parks (Fig. 3, Table 4). However, woodpecker density decreased by $42.2 \% \pm 9.64$ (SD) in Conguillío National Park, while in Nahuelbuta National Park it increased by $34.3 \% \pm 20.65$ (SD; Fig. 3, Table 4). The detection probability showed no significant annual variation (Table 4).

Fig. 2. Bayesian estimates (points) for the density of Magellanic Woodpeckers (Campephilus magellanicus) as a function of Plant Senescence Reflectance Index. The exponential line and its confidence intervals are predicted from $\mathrm{N}$-mixture Bayesian models.

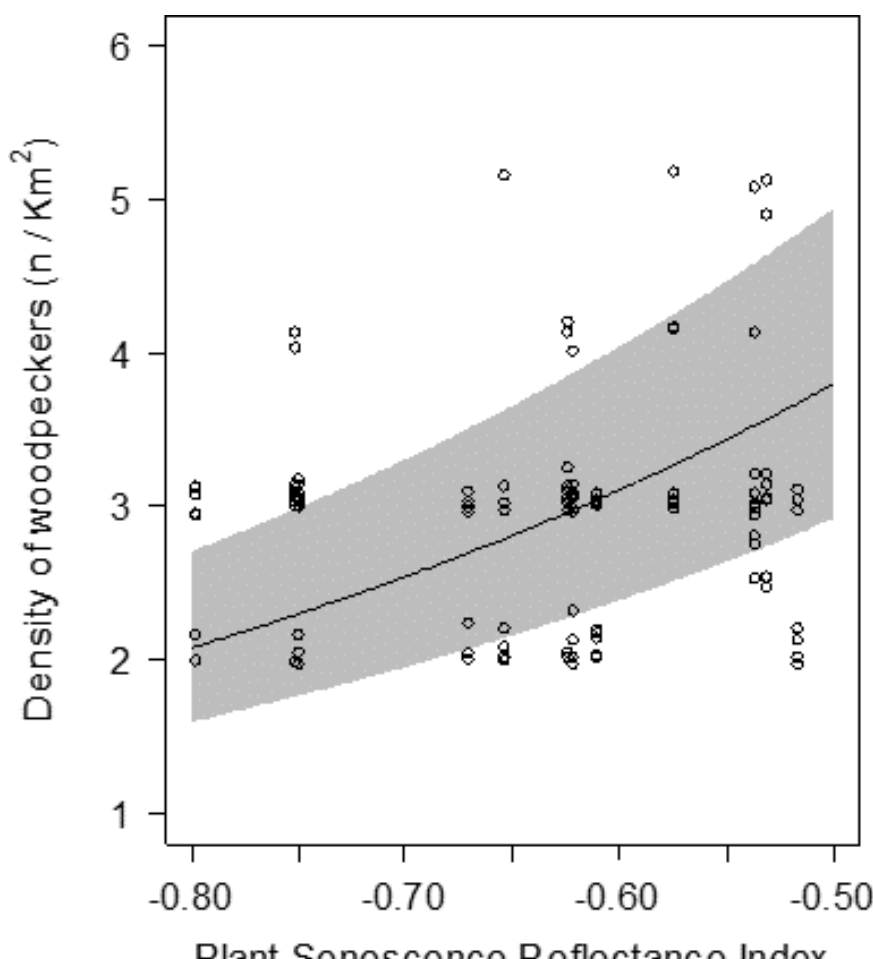

Plant Senescence Reflectance Index 
Table 3. Coefficients from the two best-supported Bayesian N-mixture CAR models explaining the abundance of Magellanic Woodpeckers (Campephilus magellanicus) in the studied national parks. The mean, standard deviations (SD), p-value, and 95\% lower and upper Bayesian credible intervals (CI) are presented. For comparison reasons, coefficients for Year 2016, reproductive season and forest of $N$. dombeyi - Monkey puzzle tree were set to be zero.

\begin{tabular}{|c|c|c|c|c|c|c|c|}
\hline Function & Variable & Mean & SD & Lower CI & Upper CI & p-value & Rhat \\
\hline \multicolumn{8}{|c|}{ Model $1(\Delta \mathrm{DIC}=0.00)$} \\
\hline \multirow[t]{3}{*}{$\lambda$} & N. pumilio - Monkey puzzle tree & 0.48 & 0.2 & 0.08 & 0.87 & 0.01 & 1.0 \\
\hline & N. antarctica-Monkey puzzle tree & 0.01 & 0.34 & -0.69 & 0.65 & 0.53 & 1.0 \\
\hline & N. antarctica & -0.09 & 0.23 & -0.56 & 0.35 & 0.56 & 1.0 \\
\hline \multirow[t]{4}{*}{$\mathrm{p}$} & Year 1996 & 0.02 & 3.19 & -6.26 & 6.24 & 0.49 & 1.0 \\
\hline & Year 1997 & 0 & 3.16 & -6.26 & 6.18 & 0.51 & 1.0 \\
\hline & Year 1998 & 0.02 & 3.15 & -6.17 & 6.14 & 0.5 & 1.0 \\
\hline & Postreproductive season & 0.04 & 3.15 & -6.1 & 6.18 & 0.49 & 1.0 \\
\hline \multicolumn{8}{|c|}{ Model $2(\Delta \mathrm{DIC}=1.58)$} \\
\hline \multirow[t]{7}{*}{$\lambda$} & PSRI & 1.9 & 1.08 & 0.01 & 4.03 & 0.04 & 1.0 \\
\hline & Year 1996 & 0.26 & 0.22 & -0.15 & 0.69 & 0.33 & 1.0 \\
\hline & Year 1997 & -0.04 & 3.16 & -6.26 & 6.1 & 0.52 & 1.0 \\
\hline & Year 1998 & -0.01 & 3.16 & -6.21 & 6.18 & 0.51 & 1.0 \\
\hline & N. pumilio - Monkey puzzle tree & 0.37 & 0.21 & -0.01 & 0.78 & 0.03 & 1.0 \\
\hline & N. antarctica - Monkey puzzle & -0.1 & 0.34 & -0.8 & 0.55 & 0.58 & 1.0 \\
\hline & N. antarctica & -0.19 & 0.24 & -0.67 & 0.27 & 0.62 & 1.0 \\
\hline \multirow[t]{7}{*}{$\mathrm{p}$} & Year 1996 & -0.03 & 3.17 & -6.28 & 6.14 & 0.51 & 1.0 \\
\hline & Year 1997 & 0.02 & 3.17 & -6.2 & 6.25 & 0.5 & 1.0 \\
\hline & Year 1998 & 0.01 & 3.14 & -6.14 & 6.12 & 0.5 & 1.0 \\
\hline & N. pumilio - Monkey puzzle tree & 0.03 & 3.17 & -6.13 & 6.22 & 0.49 & 1.0 \\
\hline & N. antarctica - Monkey puzzle tree & 0 & 3.15 & -6.16 & 6.18 & 0.5 & 1.0 \\
\hline & N. antarctica & 0.02 & 3.17 & -6.2 & 6.21 & 0.5 & 1.0 \\
\hline & Postreproductive season & 0 & 3.19 & -6.2 & 6.22 & 0.49 & 1.0 \\
\hline
\end{tabular}

Fig. 3. Boxplots for the yearly Bayesian estimates (Mean and $95 \%$ CI) of the Magellanic Woodpecker (Campephilus magellanicus) density $\left(\mathrm{n} / \mathrm{km}^{2}\right)$ at two different national parks in central-southern Chile.
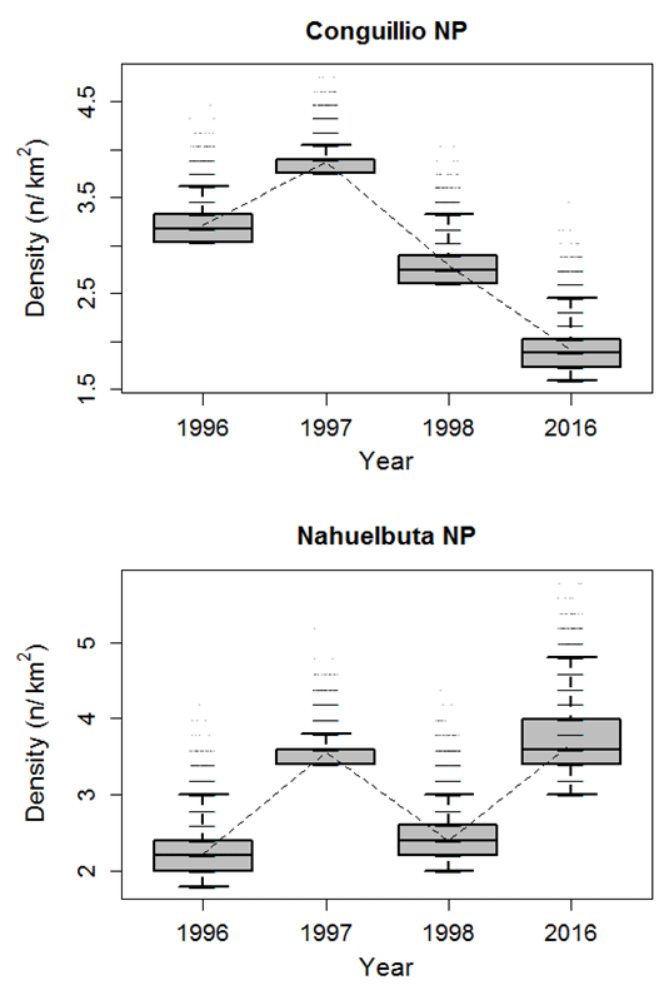

\section{DISCUSSION}

Persistence of woodpecker populations in protected areas requires sufficient availability of old-growth forests (e.g., Lammertink 2004) that provide woodpeckers with coarse woody debris, snags, as well as large living trees suitable for foraging and nesting (Angelstam and Mikusinski 1994, Vergara and Schlatter 2004, Drever and Martin 2010, Lorenz et al. 2016). Although systematic and regular time-series data are required to assess population dynamics and demography, the results of this study largely contribute to understanding the bidecadal variation of local woodpecker populations inhabiting two national parks (Conguillío and Nahuelbuta National Parks). Despite significant bidecadal variation in woodpecker populations living in centralsouthern Chilean national parks, these parks had contrasting population trends, with woodpeckers in the Nahuelbuta and Conguillío National Parks exhibiting increasing and declining trends, respectively. The pattern of population decline in Conguillío National Park suggests that this park may be falling short of its goal to protect viable populations of forest wildlife. At this point, the causes of the declines are uncertain, but we note that the Conguillío National Park has experienced large recent forest disturbances. Indeed, recent fires have destroyed at least 35 $\mathrm{km}^{2}$ of native forest in Conguillío. Thus, our findings paired with what we have learned about the ecology of woodpeckers suggest that populations may be limited by availability of suitable habitat. However, the declining status of the woodpecker population in the Conguillío park should be confirmed through identifying proximate mechanisms of population change, such as survival and reproduction success.

Our study suggests that woodpeckers responded to forest conditions, and that remotely-sensed estimates of habitat quality were not homogeneous within or among national parks. Old- 
Table 4. Bayesian estimates of the yearly mean density and detection probability of Magellanic Woodpeckers (Campephilus magellanicus; Mean \pm SD) for two national parks (NP), as fitted by the best-supported model (Table 2). Different letters indicate significant differences between years for the same park, as evaluated through their Bayesian credible intervals (CI). Bidecadal (1990s vs. 2016) variation (\%) in density $( \pm \mathrm{SD})$ and its $\mathrm{p}$-values are also shown for each park $(* \mathrm{p}<0.05 ; * * \mathrm{p}<0.001)$.

\begin{tabular}{|c|c|c|c|c|}
\hline \multirow[b]{2}{*}{ Year } & \multicolumn{2}{|c|}{ Conguillio NP } & \multicolumn{2}{|c|}{ Nahuelbuta NP } \\
\hline & Density $\left(\mathrm{n} / \mathrm{km}^{2}\right)$ & $\begin{array}{l}\text { Detection probablity } \\
\text { (p) }\end{array}$ & Density $\left(\mathrm{n} / \mathrm{km}^{2}\right)$ & Detection probablity $(\mathrm{p})$ \\
\hline 1996 & $3.21 \pm 0.17 \mathrm{a}$ & $0.39 \pm 0.22$ & $2.22 \pm 0.32 \mathrm{a}$ & $0.46 \pm 0.23$ \\
\hline 1997 & $3.87 \pm 0.14 b$ & $0.47 \pm 0.24$ & $3.56 \pm 0.19 \mathrm{~b}$ & $0.41 \pm 0.23$ \\
\hline 1998 & $2.79 \pm 0.18 \mathrm{c}$ & $0.39 \pm 0.24$ & $2.40 \pm 0.31 \mathrm{a}, \mathrm{d}$ & $0.44 \pm 0.25$ \\
\hline 1990 's & $3.29 \pm 0.10 \mathrm{a}$ & $0.42 \pm 0.23$ & $2.73 \pm 0.17 \mathrm{~d}$ & $0.44 \pm 0.23$ \\
\hline 2016 & $1.90 \pm 0.23$ & $0.47 \pm 0.25$ & $3.67 \pm 0.41$ & $0.44 \pm 0.25$ \\
\hline 20 -y change in density $(\%)$ & $-42.53 \pm 9.64 * * *$ & & $34.28 \pm 20.65^{*}$ & \\
\hline
\end{tabular}

growth $N$. pumilio-Monkey puzzle forest and forests with senescent trees provide woodpeckers with suitable habitat conditions for foraging and nesting, as suggested by previous studies (Espinosa et al. 2016). Indeed, forest dominated by Monkey puzzle and Nothofagus trees, and especially N. pumilio, might contain a more abundant and richer biota of wood boring insects, the main prey of woodpeckers (Peña 1960, Espinosa et al. 2016), while the senescent trees, i.e., trees with larger PSRI values, are strongly associated with these insects (Vergara et al. 2017). The forest ecosystems we studied host 21 species of longhorn beetles, which are potential prey for Magellanic Woodpeckers, and mostly associated with Monkey puzzle and $N$. pumilio trees (Barriga et al. 1993; Fierro and Vergara, unpublished manuscript). Among beetles, the large Microplophorus magellanicus is known to depend upon $N$. pumilio trees at advanced stages of decay (Vergara et al. 2017).

The relatively small amount of forest $\left(<240 \mathrm{~km}^{2}\right)$ being protected by the studied national parks in addition to the large territory sizes of Magellanic Woodpeckers $\left(\sim 1.0 \quad \mathrm{~km}^{2}\right.$; Ojeda and Chazarreta 2014) raises the question of the size of national parks needed to maintain viable woodpecker populations. However, inferences from population viability analysis show population persistence of large woodpeckers with a few reproductive individuals (Mattsson et al. 2008). Understanding how forest disturbances affect viability of Magellanic Woodpecker populations requires long-term demographic studies supporting limitations in the habitat quality and quantity provided by Chilean national parks (Simonetti and Mella 1997).

Large-scale wildfires are increasingly common in southern Chile, and thus becoming a potential source of population decline in this region. Conguillío national park experienced a large fire during 2015, after being affected by the Llaima Volcano eruption during 2008. Large fires could be associated with regional climate change (with drier summers and reduced winter rains) as well as uncontrolled tourism and illegal human activities within and surrounding the national park (González et al. 2005, GonzálezOlabarria and Pukkala 2011). Short- and midterm effects of fires, and the extent to which they interact with human activities and volcanic eruptions, should be further explored, especially given that Magellanic Woodpeckers may also take advantage of forest disturbances (e.g., Soto et al. 2012). In fact, under certain circumstances, fires might benefit Magellanic Woodpeckers by accelerating tree decay rates, as observed in woodpeckers inhabiting forest of the northern hemisphere (Koivula and Schmiegelow 2007, Hanson and North 2008, Saracco et al. 2011, Rota et al. 2014). Woodpeckers may respond opportunistically to improved habitat quality after forest fires, thus complementing the foraging or nesting needs they meet in undisturbed forest (Tremblay et al. 2009). Conversely, native forest in the Nahuelbuta National Park, where the woodpecker population increased over the study period, has not experienced large-extent fires within the last 40 years. Nahuelbuta National Park may provide more stable conditions for Magellanic Woodpeckers because of its topographic and geographic position, near the coastal areas and far from the volcanoes along the Andes Cordillera. Indeed, because of its biogeographic history, the reason it remained isolated as an island during the last glacial periods (Villagrán 1991, Armesto et al. 1994), the Nahuelbuta National Park supports a richer assemblage of long-horn beetle species (Peña 1960), thus providing a more diverse, and perhaps more abundant, prey base for woodpeckers. However, the long-term ability of Nahuelbuta National Park to sustain woodpecker populations may be compromised by increased susceptibility to wildfire because of proximity to large extensions of exotic plantations (drier regimes).

Although extensive forests remain in the Patagonian and SubAntarctic Ecoregions, our results suggest that temperate forests in central-southern Chile are not sufficiently protected to ensure persistence of the local populations of Magellanic Woodpeckers in the northern range of this species distribution. Continuing land use changes and deforestation may threaten small populations of woodpeckers living in this region. In this way, protected areas located along the Andes mountain range, such as the Conguillío National Park, may fail to conserve Magellanic Woodpeckers and potentially other forest biota, given that woodpeckers are closely associated with many other forest specialists (Garmendia et al. 2006, Roberge et al. 2008b). Further studies should address how accelerating land-use change from agricultural intensification, forestry, exotic plantations, and urbanization around the southern Chile national parks may contribute to declines of Magellanic Woodpeckers, as has been assessed for other woodpecker species (e.g., see Gjerde et al. 2005, Roberge et al. 2008a). Regional planning intended to protect large remnants of old-growth native forest while increasing the structural connectivity of protected areas should offer an opportunity to conserve Magellanic Woodpeckers in southern Chile. 
Avian Conservation and Ecology 12(2): 15

Responses to this article can be read online at:

http://www.ace-eco.org/issues/responses.php/1106

\section{Acknowledgments:}

FONDECYT Grant No. 1131133, Proyecto Basal USA1555, and the Athena Fund of the Cornell Lab of Ornithology founded this study. LOM acknowledges Jaime Cárcamo and Segundo Oliva and the staff of CONAF IX region for their support on field surveys. GES acknowledges Wesley Hochachka from the Cornell Lab of Ornithology and Mario Nazar for their technical support.

\section{LITERATURE CITED}

Angelstam, P., and G. Mikusinski. 1994. Woodpecker assemblages in natural and managed boreal and hemiboreal forest - a review. Annales Zoologici Finnici 31:157-172.

Araújo, M. B., P. H. Williams, and A. Turner. 2002. A sequential approach to minimise threats within selected conservation areas. Biodiversity and Conservation 11:1011-1024. http://dx.doi. org/10.1023/A:1015809008522

Armesto, J., C. Villagrán, and C. Donoso. 1994. La historia del bosque templado chileno. Ambiente y Desarrollo 10:66-72.

Barriga, J. E., T. Curkovic, T. Fichet, J. L Henriquez, and J. Macaya. 1993. Nuevos antecedentes de coleópteros xilófagos y plantas hospederas en Chile, con una recopilación de citas previas. Revista Chilena de Entomologia 20:65-91.

Blanc, L. A., and K. Martin. 2012. Identifying suitable woodpecker nest trees using decay selection profiles in trembling aspen (Populus tremuloides). Forest Ecology and Management 286:192-202. http://dx.doi.org/10.1016/j.foreco.2012.08.021

Bücking, W. 2003. Are there threshold numbers for protected forests? Journal of Environmental Management 67:37-45. https:// doi.org/10.1016/S0301-4797(02)00186-X

Bull, E. L., N. Nielsen-Pincus, B. C. Wales, and J. L. Hayes. 2007. The influence of disturbance events on Pileated Woodpeckers in Northeastern Oregon. Forest Ecology and Management 243:320-329. http://dx.doi.org/10.1016/j.foreco.2007.03.031

Burns, P. A., K. M. C. Rowe, B. P. Holmes, and K. C. Rowe. 2016. Historical resurveys reveal persistence of smoky mouse (Pseudomys fumeus) populations over the long-term and through the short-term impacts of fire. Wildlife Research 42:668-677. http://dx.doi.org/10.1071/WR15096

Chandler, R. B., and J. A. Royle. 2013. Spatially explicit models for inference about density in unmarked or partially marked populations. Annals of Applied Statistics 7:936-954. http://dx.doi. org/10.1214/12-AOAS610

Chazarreta, M. L., V. S. Ojeda, and M. Lammertink. 2012. Morphological and foraging behavioral differences between sexes of the Magellanic Woodpecker (Campephilus magellanicus). Ornitología Neotropical 23:529-544.

Chazarreta, M. L., V. S. Ojeda, and A. Trejo. 2011. Division of labour in parental care in the Magellanic Woodpecker
Campephilus magellanicus. Journal of Ornithology 152:231-242. http://dx.doi.org/10.1007/s10336-010-0570-4

Corporación Nacional Forestal (CONAF). 2011. Catastro vegetacional. CONAF, Ministry of Agriculture, Santiago, Chile. [online] URL: http://www.conaf.cl/nuestros-bosques/bosquesen-chile/catastro-vegetacional/

Drever, M. C., K. E. Aitken, A. R. Norris, and K. Martin. 2008. Woodpeckers as reliable indicators of bird richness, forest health and harvest. Biological Conservation 141:624-634. http://dx.doi. org/10.1016/j.biocon.2007.12.004

Drever, M. C., and K. Martin. 2010. Response of woodpeckers to changes in forest health and harvest: implications for conservation of avian biodiversity. Forest Ecology and Management 259:958-966. http://dx.doi.org/10.1016/j.foreco.2009.11.038

Espinosa, A., S. Aravena, H. Sandoval, N. Ojeda, and M. Á. Herrera. 2016. Feeding habitat of the Magellanic Woodpecker (Campephilus magellanicus) across forest ecosystems at Nahuelbuta National Park, La Araucanía Region, Chile. Bosque 37:347-358. http://dx.doi.org/10.4067/S0717-92002016000200013

Fogg, A. M., L. J. Roberts, and R. D. Burnett. 2014. Occurrence patterns of Black-backed Woodpeckers in green forest of the Sierra Nevada Mountains, California, USA. Avian Conservation and Ecology 9(2):3. http://dx.doi.org/10.5751/ACE-00671-090203

Garmendia, A., S. Cárcamo, and O. Schwendtner. 2006. Forest management considerations for conservation of Black Woodpecker Dryocopus martius and White-backed Woodpecker Dendrocopos leucotos populations in Quinto Real (Spanish Western Pyrenees). Biodiversity and Conservation 15:1399-1415. http://dx.doi.org/10.1007/s10531-005-5410-0

Gelman, A., J. B. Carlin, H. S. Stern, and D. B. Rubin. 2014. Bayesian data analysis Vol. 2. Chapman \& Hall/CRC, Boca Raton, Florida, USA.

Gjerde, I., M. Sætersdal, and T. Nilsen. 2005. Abundance of two threatened woodpecker species in relation to the proportion of spruce plantations in native pine forests of western Norway. Biodiversity and Conservation 14:377-393. http://dx.doi. org/10.1007/s10531-004-6065-y

González, M. E., T. T. Veblen, and J. S. Sibold. 2005. Fire history of Araucaria-Nothofagus forests in Villarrica National Park, Chile. Journal of Biogeography 32:1187-1202. http://dx.doi. org/10.1111/j.1365-2699.2005.01262.x

González-Olabarria, J. R., and T. Pukkala. 2011. Integrating fire risk considerations in landscape-level forest planning. Forest Ecology and Management 261:278-287. http://dx.doi.org/10.1016/ j.foreco.2010.10.017

Hanson, C. T., and M. P. North. 2008. Postfire woodpecker foraging in salvage-logged and unlogged forests of the Sierra Nevada. Condor 110:777-782. http://dx.doi.org/10.1525/cond.2008.8611

International Union for Conservation of Nature and Natural Resources (IUCN). 2017. The IUCN Red List of Threatened Species. Version 2015.4. IUCN, Cambridge, UK. [online] URL: http://www.iucnredlist.org 
Koivula, M. J., and F. K. Schmiegelow. 2007. Boreal woodpecker assemblages in recently burned forested landscapes in Alberta, Canada: effects of post-fire harvesting and burn severity. Forest Ecology and Management 242:606-618. http://dx.doi.org/10.1016/ j.foreco.2007.01.075

Kumar, R., G. Shahabuddin, and A. Kumar. 2014. Habitat determinants of woodpecker abundance and species richness in sub-Himalayan dipterocarp forests of north-west India. Acta Ornithologica 49:243-256. http://dx.doi.org/10.3161/173484714X687136

Lammertink, M. 2004. A multiple site comparison of woodpecker communities in Bornean lowlands and hill forest. Conservation biology 18:746-757. http://dx.doi.org/10.1111/j.1523-1739.2004.00046. $\mathrm{x}$

Lammertink, M. 2014. Trends in threat status and priorities in conservation of the woodpeckers of the world. Acta Ornithologica 49:207-219. http://dx.doi.org/10.3161/173484714X687109

Lammertink, M., D. M. Prawiradilaga, U. Setiorini, T. Z. Naing, J. W. Duckworth, and S. B. Menken. 2009. Global population decline of the Great Slaty Woodpecker (Mulleripicus pulverulentus). Biological Conservation 142:166-179. http://dx. doi.org/10.1016/j.biocon.2008.10.010

Lorenz, T. J., K. T. Vierling, J. M. Kozma, and J. E. Millard. 2016. Foraging plasticity by a keystone excavator, the white-headed woodpecker, in managed forests: Are there consequences for productivity? Forest Ecology and Management 363:110-119. http://dx.doi.org/10.1016/j.foreco.2015.12.021

Lunn, D., D. Spiegelhalter, A. Thomas, and N. Best. 2009. The BUGS project: evolution, critique and future directions. Statistics in Medicine 28:3049-3067. http://dx.doi.org/10.1002/sim.3680

Mattsson, B. J., R. S. Mordecai, M. J. Conroy, J. T. Peterson, R. J. Cooper, and H. Christensen. 2008. Evaluating the small population paradigm for rare large-bodied woodpeckers, with implications for the Ivory-billed Woodpecker. Avian Conservation and Ecology 3(2):5. http://dx.doi.org/10.5751/ACE-00255-030205

Melletti, M., and V. Penteriani. 2003. Nesting and feeding tree selection in the endangered White-backed Woodpecker, Dendrocopos leucotos lilfordi. Wilson Bulletin 115:299-306. http:// dx.doi.org/10.1676/03-022

Merzlyak, M. N., A. A. Gitelson, O. B. Chivkunova, and V. Y. Rakitin. 1999. Non-destructive optical detection of pigment changes during leaf senescence and fruit ripening. Physiologia Plantarum 106:135-141. http://dx.doi.org/10.1034/

j.1399-3054.1999.106119.x

Mikusinski, G., 2006. Woodpeckers: distribution, conservation, and research in a global perspective. Annales Zoologici Fennici 43:86-95.

Nappi, A., P. Drapeau, and A. Leduc. 2015. How important is dead wood for woodpeckers foraging in eastern North American boreal forests? Forest Ecology and Management 346:10-21. http:// dx.doi.org/10.1016/j.foreco.2015.02.028

Noss, R. F. 2000. Maintaining the ecological integrity of landscapes and ecoregions. Island Press, Washington, D.C., USA.
Noss, R. F., W. J. Platt, B. A. Sorrie, A. S. Weakley, D. B. Means, J. Costanza, and R. K. Peet. 2015. How global biodiversity hotspots may go unrecognized: lessons from the North American Coastal Plain. Diversity and Distributions 21:236-244. http://dx. doi.org/10.1111/ddi.12278

Ojeda, V. S., and L. Chazarreta. 2006. Provisioning of Magellanic Woodpecker (Campephilus magellanicus) nestlings with vertebrate prey. Wilson Journal of Ornithology 118:251-254. http://dx.doi.org/10.1676/05-014.1

Ojeda, V. S., and L. Chazarreta. 2014. Home range and habitat use by Magellanic Woodpeckers in an old-growth forest of Patagonia. Canadian Journal of Forest Research 44:1265-1273. http://dx.doi.org/10.1139/cjfr-2013-0534

Ojeda, V. S., I. Soto, A. Espinosa, and J. L. Galaz. 2011. Plan Nacional de Conservación del Carpintero negro Campephilus magellanicus (King, 1828) en Chile. Technical Report. Corporación Nacional Forestal, Ministry of Agriculture, Santiago, Chile.

Otero, L. 2001. La huella del fuego. Historia de los bosques nativos. Poblamiento y cambios en el paisaje del sur de Chile. Pehuén Editores 1-177.

Parks, A. M., M. A. Jenkins, K. E. Woeste, and M. E. Ostry. 2013. Conservation status of a threatened tree species: establishing a baseline for restoration of Juglans cinerea L. in the southern Appalachian Mountains, USA. Natural Areas Journal 33:413-426. http://dx.doi.org/10.3375/043.033.0404

Pasinelli, G. 2006. Population biology of European wood-pecker species: a review. Annales Zoologici Fennici 43:96-111.

Pasinelli, G. 2007. Nest site selection in Middle and Great Spotted Woodpeckers Dendrocopos medius \& D. major: implications for forest management and conservation. Biodiversity and Conservation 16:1283-1298. http://dx.doi.org/10.1007/s10531-007-9162$\mathrm{x}$

Pauchard, A., and P. Villaroel. 2002. Protected areas in Chile: history, current status and challenges. Natural Areas Journal 22:318-330.

Paudel, P. K., and J. T. Heinen. 2015. Conservation planning in the Nepal Himalayas: effectively (re)designing reserves for heterogeneous landscapes. Applied Geography 56:127-134. http:// dx.doi.org/10.1016/j.apgeog.2014.11.018

Peña, L. 1960. Algunas observaciones sobre especies poco conocidas de Cerambycidae (Insecta-Coleoptera) de Chile. Revista Universitaria (Universidad Católica de Chile) 44:57-61.

R Development Core Team. 2008. R: A language and environment for statistical computing. R Foundation for Statistical Computing, Vienna, Austria. ISBN 3-900051-07-0. [online] URL: http://www. R-project.org

Ralph, C. J., G. R. Geupel, P. Pyle, T. E. Martin, and D. F. DeSante. 1993. Handbook of field methods for monitoring landbirds. General Technical Report PSW-GTR-144. U.S. Forest Service, Pacific Southwest Research Station, Albany, California, USA. https:// doi.org/10.2737/PSW-GTR-144 
Roberge, J.-M., P. Angelstam, and M.-A. Villard. $2008 a$. Specialized woodpeckers and naturalness in hemiboreal forests: deriving quantitative targets for conservation planning. Biological Conservation 141:997-1012. http://dx.doi.org/10.1016/j.

biocon.2008.01.010

Roberge, J.-M., G. Mikusiński, and S. Svensson. 2008b. The White-backed Woodpecker: umbrella species for forest conservation planning? Biodiversity and Conservation 17:2479-2494. http://dx.doi.org/10.1007/s10531-008-9394-4

Rodrigues, A. S., S. J. Andelman, M. I. Bakarr, L. Boitani, T. M. Brooks, R. M. Cowling, L. D. C. Fishpool, G. A. B. da Fonseca, K. J. Gaston, M. Hoffmann, et al. 2004. Effectiveness of the global protected area network in representing species diversity. Nature 428:640-643. http://dx.doi.org/10.1038/nature02422

Rota, C. T., M. A. Rumble, J. J. Millspaugh, C. P. Lehman, D. C. Kesler. 2014. Space-use and habitat associations of Black-backed Woodpeckers (Picoides arcticus) occupying recently disturbed forests in the Black Hills, South Dakota. Forest Ecology and Management 313:161-168. http://dx.doi.org/10.1016/j.foreco.2013.10.048

Roux, D. J., J. L. Nel, P. J. Ashton, A. R. Deacon, F. C. de Moor, D. Hardwick, L. Hill, C. J. Kleynhans, G. A. Maree, J. Moolman, and R. J. Scholes. 2008. Designing protected areas to conserve riverine biodiversity: lessons from a hypothetical redesign of the Kruger National Park. Biological Conservation 141:100-117. http://dx.doi.org/10.1016/j.biocon.2007.09.002

Royle, J. A. 2004. $N$-mixture models for estimating population size from spatially replicated counts. Biometrics 60:108-115. http://dx.doi.org/10.1111/j.0006-341X.2004.00142.x

Saracco, J. F., R. B. Siegel, and R. L. Wilkerson. 2011. Occupancy modeling of Black-backed Woodpeckers on burned Sierra Nevada forests. Ecosphere 2:1-17. http://dx.doi.org/10.1890/ ES10-00132.1

Schlatter, R. P., and P. Vergara. 2005. Magellanic Woodpecker (Campephilus magellanicus) sap feeding and its role in the Tierra del Fuego forest bird assemblage. Journal of Ornithology 146:188-190. http://dx.doi.org/10.1007/s10336-004-0069-y

Setterington, M. A., I. D. Thompson, and W. A. Montevecchi. 2000. Woodpecker abundance and habitat use in mature balsam fir forests in Newfoundland. Journal of Wildlife Management 64:335-345. http://dx.doi.org/10.2307/3803231

Short, L. L. 1970. The habits and relationships of the Magellanic Woodpecker. Wilson Bulletin 82:115-129.

Simonetti, J. A., and J. E. Mella. 1997. Park size and the conservation of Chilean mammals. Revista Chilena de Historia Natural 70:213-220.

Soto, G. E., C. G. Pérez-Hernández, I. J. Hahn, A. D. Rodewald, and P. M. Vergara. 2017. Tree senescence as a direct measure of habitat quality: linking red-edge vegetation indices to space use by Magellanic Woodpeckers. Remote Sensing of Environment 193:1-10. http://dx.doi.org/10.1016/j.rse.2017.02.018

Soto, G. E., P. M. Vergara, M. E. Lizama, C. Celis, R. Rozzi, Q. Duron, I. J. Hahn, and J. E. Jiménez. 2012. Do beavers improve the habitat quality for Magellanic Woodpeckers? Bosque 33:271-274. http://dx.doi.org/10.4067/S0717-92002012000300007
Soto, G. E., P. M. Vergara, A. Smiley, M. E. Lizama, D. MoreiraArce, and R. A. Vásquez. 2016. Lethal agonistic behavior between two male Magellanic Woodpeckers Campephilus magellanicus observed in the Cape Horn area. Wilson Journal of Ornithology 128:180-184. http://dx.doi.org/10.1676/1559-4491-128.1.180

Spiegelhalter, D., A. Thomas, N. Best, and D. Lunn. 2003. WinBUGS user manual.

Squeo, F. A., R. A. Estévez, A. Stoll, C. F. Gaymer, L. Letelier, and L. Sierralta. 2012. Towards the creation of an integrated system of protected areas in Chile: achievements and challenges. Plant Ecology \& Diversity 5:233-243. http://dx.doi. org/10.1080/17550874.2012.679012

Sturtz, S., U. Ligges, and A. Gelman. 2005. R2WinBUGS: a package for running WinBUGS from R. Journal of Statistical Software 12:1-16. http://dx.doi.org/10.18637/jss.v012.i03

Tognelli, M. F., P. I. R. de Arellano, and P. A. Marquet. 2008. How well do the existing and proposed reserve networks represent vertebrate species in Chile? Diversity and Distributions 14:148-158. http://dx.doi.org/10.1111/j.1472-4642.2007.00437.x

Tremblay, J. A., J.Ibarzabal, C. Dussault, and J.-P. L. Savard. 2009. Habitat requirements of breeding Black-backed Woodpeckers (Picoides arcticus) in managed, unburned boreal forest. Avian Conservation and Ecology 4(1):2. http://dx.doi.org/10.5751/ ACE-00297-040102

Vergara, P., and R. P. Schlatter. 2004. Magellanic Woodpecker (Campephilus magellanicus) abundance and foraging in Tierra del Fuego, Chile. Journal of Ornithology 145:343-351. http://dx.doi. org/10.1007/s10336-004-0052-7

Vergara, P. M., J. E. Jiménez, and R. P. Schlatter. 2010. Effective point-count duration for estimating bird species' richness in Chilean forests. Zoological Studies 49:381-391.

Vergara, P. M., L. O. Meneses, A. A. Grez, M. S. Quiroz, G. E. Soto, C. G. Pérez-Hernández, P. A. Diaz, I. J. Hahn, and A. Fierro. 2017. Occupancy pattern of a long-horned beetle in a variegated forest landscape: linkages between tree quality and forest cover across spatial scales. Landscape Ecology 32:279-293. http://dx. doi.org/10.1007/s10980-016-0443-1

Vergara, P. M., A. Rivera-Hutinel, A. A. Farías, H. Cofré, H. Samaniego, and I. J. Hahn. 2014. ¿Cómo Responden los Animales del Bosque a las Perturbaciones Antropogénicas? Pages 235-254 in C. Donoso, M. E. González, and A. Lara, editors. Ecología Forestal: Bases para el Manejo Sustentable y Conservación de los Bosques Nativos de Chile. Ediciones Universidad Austral de Chile, Valdivia, Chile.

Vergara, P. M., G. E. Soto, D. Moreira-Arce, A. D. Rodewald, L. O. Meneses, and C. G. Pérez-Hernández. 2016. Foraging behaviour in Magellanic Woodpeckers is consistent with a multiscale assessment of tree quality. PLoS ONE 11(7):e0159096. http://dx.doi.org/10.1371/journal.pone.0159096

Villagrán, C. 1991. Historia de los bosques templados del Sur de Chile durante el Tardiglacial y Postglacial. Revista Chilena de Historia Natural 64:447-460.

Wilson, E. O. 1989. Threats to biodiversity. Scientific American 261:108-116. 
Zahner V., L. Sikora, and G. Pasinelli. 2012. Heart rot as a key factor for cavity tree selection in the Black Woodpecker. Forest Ecology and Management 271:98-103. http://dx.doi.org/10.1016/ j.foreco.2012.01.041 